\title{
Effect of Prosopis ruscifolia on lipid profile in alloxan-induced hyperglycemic mice and chemical characterization of alkaloid and flavonoid fractions
}

\author{
Miguel A. Campuzano-Bublitz', Elena M. G. Diarte' ${ }^{1}$, María C. Hellión-Ibarrola ${ }^{1}$, Derlis A. Ibarrola ${ }^{1}$, Nelson L. Alvarenga ${ }^{2}$, \\ María L. Kennedy ${ }^{1 *}$ \\ ${ }^{1}$ Departamento de Farmacología, Facultad de Ciencias Químicas, Universidad Nacional de Asunción, San Lorenzo, Paraguay. \\ ${ }^{2}$ Departamento de Fitoquímica, Facultad de Ciencias Químicas, Universidad Nacional de Asunción, San Lorenzo, Paraguay.
}

\begin{tabular}{l}
\hline ARTICLE INFO \\
\hline Received on: 11/03/2019 \\
Accepted on: $27 / 04 / 2019$ \\
Available online: 05/06/2019 \\
\\
\hline Key words: \\
Atherogenic index, coronary \\
risk index, lipids profile, \\
piperidine alkaloid, quercetin.
\end{tabular}

\section{INTRODUCTION}

A major symptom in Type 1 and type 2 diabetes is hyperglycemia even when the progression of the disease varies; this is due to the progressive loss of $\beta$-cell mass and/or function. Patients with hyperglycemia can develop several complications, with different rates of progression (American Diabetes Association,

"Corresponding Author

María L. Kennedy, Departamento de Farmacología, Facultad de Ciencias Químicas, Universidad Nacional de Asunción, San Lorenzo, Paraguay. E-mail:lukernol@qui.una.py

\begin{abstract}
Diabetes mellitus interferes with the metabolism of carbohydrates, causing chronic hyperglycemia. Dyslipidemia in diabetes is a condition that leads to cardiovascular disease. This study was aimed to evaluate the effect of hydroalcoholic Prosopis ruscifolia (Pr) leaves extract on hyperglycemia and lipid profile in normo- and hyperglycemic mice. Mice hyperglycemia was induced by alloxan, animals were treated with $\operatorname{Pr}(50,100,200 \mathrm{mg} / \mathrm{kg}$, p.o., 28 days). Fasted blood glucose level on days 7, 14, 21, and 28 was determined. Blood glucose remained within the normal range in the groups of normoglycemic animals treated with Pr. In the hyperglycemic animals, $100 \mathrm{mg} / \mathrm{kg}$ of Pr extract reduced the glycemia, this effect became markedly evident since day 7 , until the end of experimental period $(p<$ 0.0001 ), the total reduction reached was $60 \%$. The lipid profile of normal and hyperglycemic mice was evaluated with $100 \mathrm{mg} / \mathrm{kg}$, on day 28 . A non-significant increase in total cholesterol and low density cholesterol, in hyperglycemic animals treated with vehicle, and a statistically significant increase $(p<0.0001)$ in the level of triglyceride and very low density cholesterol (VLDL) level $(p<0.0001)$ in normoglycemic animals treated with Pr, compared to the control group were denoted. This could indicate that $\mathrm{Pr}$ has a stimulating action on insulin secretion, since hyperinsulinemia is also associated with an increase in the quantity of atherogenic particles of VLDL cholesterol and triglycerides. The coronary risk index and the atherogenic index of hyperglycemic animals treated with Pr showed a reduction compared with the untreated hyperglycemic ones. The presence of three piperidine alkaloids, juliprosopine, 3"'"Oxo-juliprosopine, and julifloridine, previously isolated from $P$. juliflora, was confirmed. Also, the presence of the flavonoid quercetin was detected in this plant. Those compounds are strong candidates presumably responsible for imparting the effect on glycemia and lipid profile reported here.
\end{abstract}

2017). Dyslipidemia is a common feature of diabetes and a risk factor for cardiovascular disease in these patients. High level of low density lipoprotein cholesterol (LDL-c) is a well-known risk factor but patient with type 2 diabetes have a greater risk of cardiovascular disease mortality (Chehade et al., 2013). People with diabetes can have various types of dyslipidemias (Hachem and Mooradian, 2006), but a major risk factor of cardiovascular diseases is observed in patients with hypertriglyceridemia, reduced high density lipoprotein cholesterol (HDL-c), and increased small dense LDL (Mooradian, 2009).

Diabetes mellitus dyslipidemia is attributed mostly to insulin resistance and insulin deficiency; being the main features 
increased level of very low-density lipoprotein (VLDL) and triglycerides (TGs), reduced level of HDL-c, and a predominance of small cholesteryl ester-poor LDL (Hachem and Mooradian, 2006). These features are due to increased free fatty-acid release from insulin-resistant fat cells. The excess risk can be attributed mainly to diabetic dyslipidemia (Chahil and Ginsberg, 2006).

On the other hand, the phenotype of patients with type 1 diabetes is closely similar to those with type 2 diabetes, showing a progressive increase in body weight and in blood pressure, and lipoprotein alterations (Chillaron et al., 2009; 2010). This entails a remarkable increase of the metabolic syndrome in these patients and therefore, of the vascular risk (Chillaron et al., 2013). Currently, scientific evidence indicates that the patients with and without diabetes have reduced risk of coronary heart disease when they undergo cholesterol reduction therapy (Baigent et al., 2005).

In Paraguayan communities, diabetes is treated using hypoglycemic medicinal plants, among them Prosopis ruscifolia (Pr), a very thorny medium size tree that grows abundantly in the Paraguayan Chaco (González Torres, 1996; Meloni et al., 2008). The indigenous population of Paraguay uses this plant as hypoglycemic and to treat hypercholesterolemia (Polini and Romero, 2013). Considering the traditional use of P. ruscifolia and a previous report of low toxicity and the effect for lowering fasting blood glucose level in alloxan induced hyperglycemic rats after acute and chronic treatment (Campuzano-Bublitz et al., 2016), the present work proposed to investigate the influence of hydroalcoholic extract of Pr after chronic oral administration, on lipid profile in normo- and hyperglycemic mice.

\section{MATERIALS AND METHODS}

\section{Plant material and extraction}

Aerial parts of Prosopis ruscifolia Griseb. (Fabaceae) were collected, identified, and dried (voucher specimen "Fátima Mereles No: 8.803"). The hydro-ethanolic extract was prepared by a conventional reflux method (Campuzano-Bublitz et al., 2016). A suspension of extract in distilled water was used in the experiment.

\section{Chemicals}

Alloxan monohydrate and sodium chloride were obtained from Sigma Chemical Company (St. Louis, MO), pentobarbital (Nembutal) from Abbott (Japan), and ethanol were purchased locally which was distilled before use. FreeStyle Glucometer (Abbott) Kits for the estimation of total cholesterol, triglyceride, and HDL-cholesterol were purchased from Human Diagnostics Worldwide reagent.

\section{Experimental animals}

The animals, Swiss albino male mice (20-30 g), were kept in usual standard condition, received commercial foods, and were fasted overnight before the experiments with free access to drinking water during the trials. All assays were conducted in accordance with the international standards of animal welfare and Bioethical Committee approved protocol was followed (CEI 134/14); the minimum number of animals were used and each animal was used once (Real Decreto 17344, 2005).

\section{HILIC LC-ESI-MS conditions for alkaloid characterization}

AWaters Acquity ultra-performance liquid chromatograph (UPLC) equipped with a quaternary solvent manager with an ESI probe and a XEVO-TQD triple quadrupole tandem mass spectrometer (Waters Corporation, Milford, MA) was employed. For the separations, a Phenomenex Kinetex hydrophilic interaction liquid chromatography (HILIC) column with a particle diameter of $1.7 \mu \mathrm{m}, 2.1 \mathrm{~mm}$ i.d. $\times 100 \mathrm{~mm}$ was used. HILIC is an alternative to separate small polar molecules on a polar stationary phase, or for separation of polar compounds that cannot be adequately resolved in reverse phase columns. Acetonitrile: water 90:10 (A) with $5 \mathrm{mM}$ ammonium formate and acetonitrile: water 50:50 (B) with $0.1 \%$ formic acid $+5 \mathrm{mM}$ ammonium formate was the mobile phase. A gradient elution was employed (flow $0.25 \mathrm{ml} /$ minute) with the following program: $0.00 \rightarrow 2.50$ minutes $100 \% \mathrm{~A}, 10.00$ minutes $0 \% \mathrm{~A}, 12.50$ minutes $0 \% \mathrm{~A}$, and 15.00 minutes $100 \%$ A maintained until 18.00 minutes. The column temperature was $40^{\circ} \mathrm{C}$ and the injection volume was $10 \mu \mathrm{l}(5 \mathrm{mg} / \mathrm{ml}$, acetonitrile as a solvent). For the characterization of the main components of the alkaloid fraction, an elution at MS SCAN mode was performed. The conditions were as follows: polarity ESI $(+)$, capillary voltage 3.70 $\mathrm{kV}$, cone voltage $35.00 \mathrm{~V}$, source temperature $150^{\circ} \mathrm{C}$, desolvation temperature $500^{\circ} \mathrm{C}$, desolvation gas flow $1,000 \mathrm{l} /$ hour.

\section{LC- ESI-MS/SIM for quercetin identification}

For quercetin identification, the same apparatus aforementioned was employed. The characterization of the compound was performed as follows: for separation, a WATERS ACQUITY UPLC BEH C18 column was used with a particle diameter of $1.7 \mu \mathrm{m}, 2.1 \mathrm{~mm}$ i.d. $\times 50 \mathrm{~mm}$. The mobile phase was composed by water with $0.1 \%$ formic acid $+0.5 \%$ ammonia (A) and methanol (B). The elution was performed in gradient mode with the following conditions: flow rate $0.3 \mathrm{ml} /$ minute, $0.00 \rightarrow 0.5090 \% \mathrm{~A}$, $0.5 \rightarrow 2.0010 \% \mathrm{~A}, 2.00 \rightarrow 4.0010 \% \mathrm{~A}, 4.00 \rightarrow 4.0115 \% \mathrm{~A}, 4.01 \rightarrow$ $5.0030 \% \mathrm{~A}, 5.00 \rightarrow 6.0055 \% \mathrm{~A}, 6.00 \rightarrow 7.0090 \% \mathrm{~A}$, and $7.00 \rightarrow$ $15.0090 \% \mathrm{~A}$. The column temperature was $40^{\circ} \mathrm{C}$ and the injection volume was $10 \mu \mathrm{l}$ (methanol as a solvent). The characterization of the compound was performed in SIR mode. The conditions were: polarity ES (-), ion mass $302.33 \mathrm{~m} / \mathrm{z}$, capillary voltage $5 \mathrm{kV}$, cone voltage $30.00 \mathrm{~V}$, dwell time 0.025 seconds, source temperature $150^{\circ} \mathrm{C}$, desolvation temperature $350^{\circ} \mathrm{C}$, and desolvation gas flow $540 \mathrm{l} /$ hour. An authentic sample $(1 \mathrm{mg} / \mathrm{ml}$, dissolved in methanol) was injected also to confirm the presence of the compound.

\section{Alloxan induced hyperglycemia and treatment}

Albino Swiss mice were kept fasted during 12 hours with free access to drinking water and treated with alloxan monohydrate (i.p.; $150 \mathrm{mg} / \mathrm{kg}$ body weight) to induce hyperglycemic condition (Dunn and McLetchie, 1943). After 48 hours, animals with a fasted blood glucose concentration higher than $200 \mathrm{mg} / \mathrm{dl}$ were considered as hyperglycemic according to the values for mice with normal glucose level declared by Zúñiga et al. (2011). Each animal received once a day for 28 days, distilled water $(0.1 \mathrm{ml} / 10 \mathrm{~g}$ of weight, p.o.) or Pr hydro-ethanolic extract $(50,100$, or $200 \mathrm{mg} / \mathrm{kg}$, p.o.), and were fed with $6 \mathrm{~g}$ /day a standard feed and water ad libitum. The influence of Pr extract on glycemia was tested in normoglycemic 
(Nveh, $\mathrm{NPr}_{50}, \mathrm{NPr}_{100}$, andNPr ${ }_{200}$ ) and hyperglycemic (Hveh, $\mathrm{HPr}_{50}$, $\mathrm{HPr}_{100}$, and $\mathrm{HPr}_{200}$ ) mice and glucose level was measured on days 0, 7, 14, 21, and 28 (García et al., 2006). Serum lipid profile was measured in four groups of mice $(n=8)$, Nveh (normoglycemic, vehicle), NPr (normoglycemic, Pr, $100 \mathrm{mg} / \mathrm{kg}$, p.o.), Hveh (hyperglycemic, vehicle), and HPr (hyperglycemic, $\operatorname{Pr}, 100 \mathrm{mg} / \mathrm{kg}$, p.o.) at the end of the 28th days of treatment.

\section{Biochemical estimations in blood and serum}

Blood from the tail vein was obtained for fasting blood glucose measurement with a glucometer. For estimating serum lipid profile, serum was separated from the blood collected by cardiac puncture after pentobarbital $(50 \mathrm{mg} / \mathrm{kg}$, i.p.) anesthesia, from overnight fasted mice on day 28. Serum total cholesterol (TC), TG, and high density lipoprotein cholesterol (HDL-c) were estimated with the reagents kits; very low density lipoprotein cholesterol (VLDL-c) and LDL-c were calculated as per Friedevald's equation. VLDL-c = Serum triglyceride/5; LDL $=\mathrm{TC}-\mathrm{VLDL}-\mathrm{c}-\mathrm{HDL}-\mathrm{c}$. Results were expressed in $\mathrm{mg} / \mathrm{dl}$. Atherogenic index (AI) was calculated as: LDL-c/ HDL-c and coronary risk index (CRI) was calculated as TC/HDL-c.

\section{Statistical analysis}

One-way analysis of variance (ANOVA) followed by Tukey's multiple comparison test using GraphPad Prism 7.0 software (GraphPad Software, Inc., CA) was performed. Results are expressed as mean $\pm \mathrm{SD}$. The level of probability $(p)$ less than 0.05 was considered as statistically significant.

\section{RESULTS AND DISCUSSION}

Alloxan causes a massive reduction of $\beta$-cells of the islets of Langerhans through its ability to induce ROS formation, resulting in the selective necrosis of beta cells and hyperglycemia (Lenzen, 2008). Prosopis ruscifolia is traditionally used for a treatment of conjunctivitis, hypercholesterolemia, and as an antidiabetic agent (Polini and Romero, 2013). In a previous study in rats, the effect of this plant was investigated and it was demonstrated that $100 \mathrm{mg} / \mathrm{kg}$ significantly reduces the glycemia in these animals (Campuzano-Bublitz et al., 2016). In this work, the effect of $P$. ruscifolia the hydro-alcoholic extract on glycemia and lipid profile in normoglycemic and alloxan induced hyperglycemic mice was evaluated.

\section{HILIC LC-ESI-MS analysis}

The elution in MS SCAN mode of the alkaloid fraction of $P$. ruscifolia showed five main peaks. The mass spectrum of the main peak at 10.26 minutes showed a molecular ion of mass $630.883 \mathrm{~m} / \mathrm{z}[\mathrm{M}+\mathrm{H}]^{+}$and two other ions at $316.167 \mathrm{~m} / \mathrm{z}$ (base peak) $[\mathrm{M}+2 \mathrm{H}]^{2+}$ and $211.222 \mathrm{~m} / \mathrm{z}[\mathrm{M}+3 \mathrm{H}]^{3+}$. These data correspond to the piperidine alkaloid juliprosopine, previously isolated from another species of the same genus, $P$. juliflora (Dos Santos et al., 2013; Nakano et al., 2004; Singh and Verma, 2012). The second majority peak at 7.72 minutes showed a molecular ion at 644.973 $m / z[\mathrm{M}+\mathrm{H}]^{+}$and a main ion (base peak) at $323.145 \mathrm{~m} / z[\mathrm{M}+2 \mathrm{H}]^{2+}$. These data are in agreement with the piperidine alkaloid 3"'-Oxojuliprosopine, also isolated from the plant mentioned above. The third main peak of the chromatogram at 3.10 minutes showed a molecular ion at $m / z 300.545[\mathrm{M}+\mathrm{H}]^{+}$that was also the base peak. The mass correspond to the piperidine alkaloid julifloridine isolated also from P. juliflora. The other two main peaks at 1.09 and 8.93 minutes were unresolved mixtures of compounds, and therefore their structures were not characterized (Fig. 1).

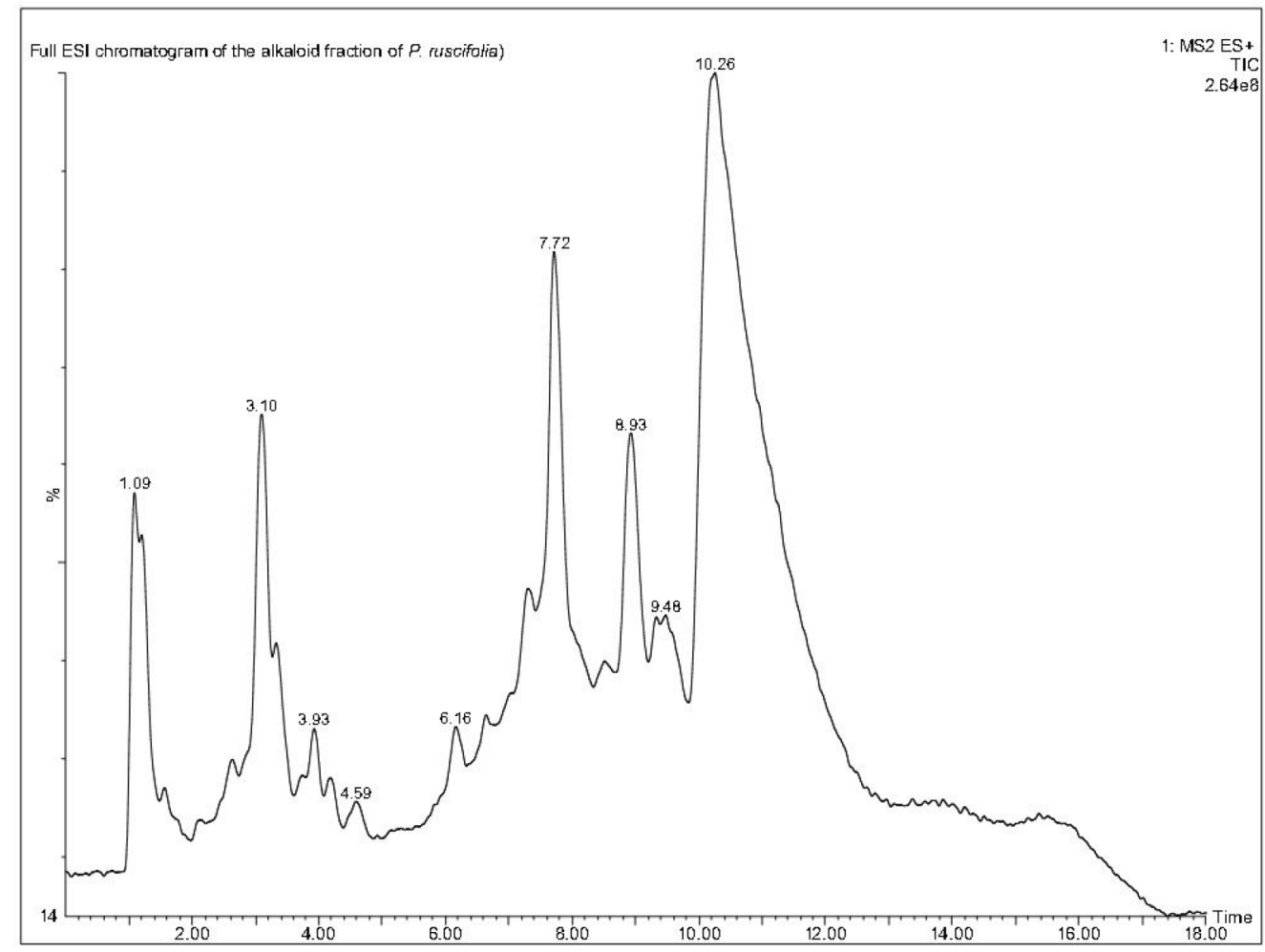

Figure 1. Full ESI-LCMS chromatogram of the alkaloid fraction of P. ruscifolia. 


\section{Quercetin identification}

The elution in SIR/MS mode showed a lone peak at 4.24 minutes. To confirm the identity of the compound, as quercetin, an authentic sample was also injected, that showed the same RT and shape as the peak of the extract (Fig. 2).

\section{Effect on glycemia level}

The effect of the extract of P. ruscifolia on the glycemia of normoglycemic and alloxan-induced hyperglycemic mice was tested $(50,100$, and $200 \mathrm{mg} / \mathrm{kg})$, eight groups were formed and mice were treated for 28 days. In the groups of normoglycemic animals, none of the three doses produced variations of the glycemia outside physiological range (data not shown). In the Nveh group (normoglycemic, water, p.o.), the glycemia level was verified at the beginning of the experiment $(139.0 \pm 12.12 \mathrm{mg} / \mathrm{dl})$ and at $7(137.7 \pm 32.85 \mathrm{mg} / \mathrm{dl}), 14(153.5 \pm 36.48 \mathrm{mg} / \mathrm{dl}), 21(142$ $\pm 18.44 \mathrm{mg} / \mathrm{dl})$, and 28 days $(128.2 \pm 17.66 \mathrm{mg} / \mathrm{dl})$. Therefore, it is concluded that the diet they received, that is, $6 \mathrm{~g}$ /day of commercial pellet did not alter the glycemia of normoglycemic mice.

In the groups of hyperglycemic animals, it was found that $100 \mathrm{mg} / \mathrm{kg}$ of Pr was the only effective dose that significantly reduced glycemia (Fig. 3); the hypoglycemic effect of the extract became markedly evident from the first measurement on day 7 and remained low until the end of the observation, contrasting with the other two groups, $\mathrm{HPr}_{50}$ and $\mathrm{HPr}_{200}$, with high serum blood glucose level until the end. Mice with alloxan-induced hyperglycemia maintained the blood glucose level significantly elevated throughout the trial $($ Hveh $=$ initial $418.0 \pm 61.48$, day $7: 311.9 \pm 80.73$, day $14: 253.4 \pm 93.24$, day $21: 307.3 \pm 120.6$, and day 28: $324.59 \pm 59.80 ; \mathrm{mg} / \mathrm{dl}$ ); and when comparing the data obtained at the end of the treatment, it has been observed a significant difference between the hyperglycemic (Hveh) and normoglycemic (Nveh) animals treated with vehicle (324.5 \pm 59.80 and $142.1 \pm 9.54, \mathrm{mg} / \mathrm{dl}$, respectively, $p<0.0001$; Fig. 3 ).

The initial glycemia in $\mathrm{HPr}_{100}$ group was $323.3 \pm 91.73$ $\mathrm{mg} / \mathrm{dl}$; after that at $7(129.9 \pm 48.09 \mathrm{mg} / \mathrm{dl}), 14(106.6 \pm 54.65$ $\mathrm{mg} / \mathrm{dl}), 21(77.88 \pm 24.75 \mathrm{mg} / \mathrm{dl})$, and 28 days $(131.627 .36 \mathrm{mg} /$ dl) were significantly lower $(p<0.0001)$. When compared, the values obtained since day 7 , in $\operatorname{HPr}_{100}$ and the Nveh groups, it was evidenced that there were no significant difference $\left(\begin{array}{ll}p & 0.05\end{array}\right)$ between them (Fig. 3). This indicates that the hydro-alcoholic extract of $P$ ruscifolia significantly reduced glycemia and, even more, these values reached normal level (Zuñiga et al., 2011) and showed similar evolution as Nveh group established in this work. Finally, comparing the groups of hyperglycemic animals, Hveh and $\operatorname{HPr}_{100}$, it was observed that at the beginning of the study (day 0 ) in both groups a high serum blood glucose level were measured, and after the seventh day, a significant decrease in glycemia was observed in the $\operatorname{HPr}_{100}$ group. The total reduction of glycemia at the end of the experiment was almost $60 \%$ (Table 1 ).

Other Prosopis species have proved their ability for lowering blood glucose level. Thus, rats treated with $P$. glandulosa resulted in significant increase in insulin levels and significant decrease in blood glucose levels (George et al., 2011). Both,

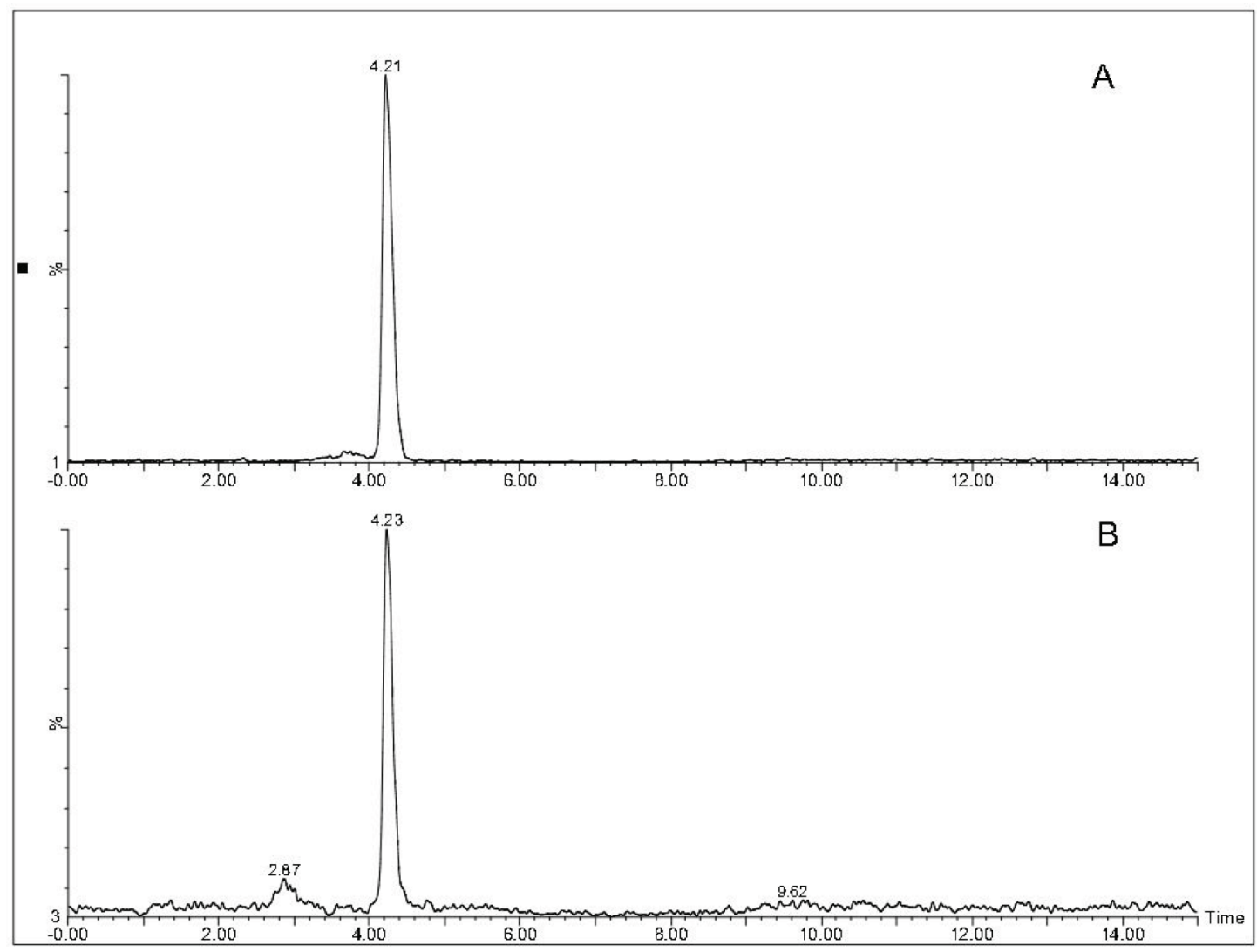

Figure 2. SIR LCMS chromatogram of quercetin. (A) Sample of P. ruscifolia. (B) Standard of quercetin. 
leaves and barks extracts of $P$. cineraria reduced blood glucose level of streptozotocin-induced diabetic Wistar rats (Sharma and Singla, 2013, Sharma et al., 2010). Other study showed that $P$. farcta reduced serum glucose level of STZ-induced diabetic rats (Dashtban et al., 2016). We have previously reported the significant reduction in blood glucose level in hyperglycemic rats, after acute and chronic oral treatment with $P$. ruscifolia hydroalcoholic leaves extract (Campuzano-Bublitz et al., 2016).

Results of this study do not allow defining the mechanism of hypoglycemic action of P. ruscifolia. Various plant metabolites possess hypoglycemic and other pharmacological properties. As previously determined (Campuzano-Bublitz et al., 2016); P. ruscifolia contain saponins, flavonoids, and alkaloids, all of them are strong candidates presumably responsible for imparting the effect on glycemia and lipid profile reported here. This antihyperglycemic action can be attributed to undamaged or residual $\beta$-cell stimulation to release insulin (Gerich, 1989), or, to an increasing formation of small $\beta$-cells as described previously in P. glandulosa (George et al., 2011). Oxidative stress and free radicals production plays a key role in diabetes (Ceriello, 2003). Compounds that are a part of $P$. ruscifolia composition have the ability to serve as antioxidants. Quercetin, previously found in $P$. farcta demonstrated the ability to regenerate pancreatic islets and probably increases insulin release (Dashtban et al., 2016; Vessal et al., 2003) and is a radical scavenger that has protective effect against oxidative stress-induced cell damage via scavenging reactive oxygen species.

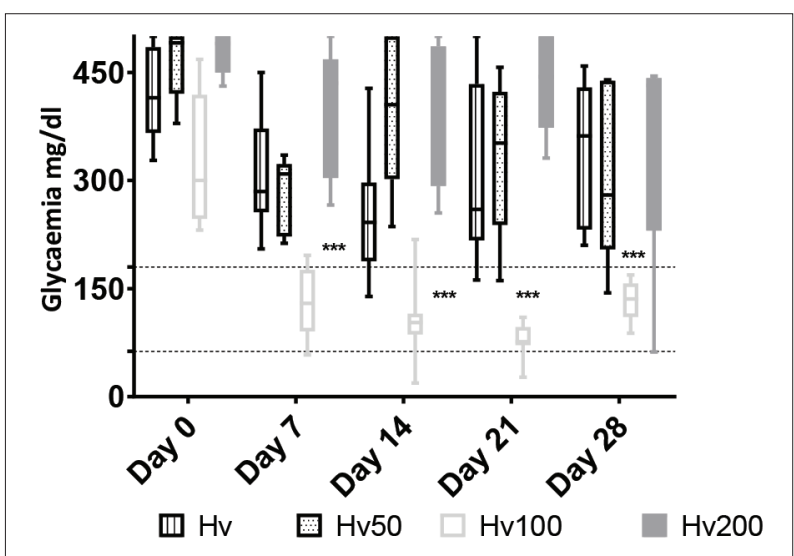

Figure 3. Glucose values of hyperglycemic mice after 28 days treatment with Prosopis ruscifolia. Each bar represents the mean \pm SD of eight animals. $* * * p<0.001$ significantly different from Hv, Tukey's Multiple Comparison test after one way ANOVA.

\section{Effect on lipid profile}

Considering the result of $P$. ruscifolia (Pr) on glycemia, and taking into account that only $100 \mathrm{mg} / \mathrm{kg}$ showed the ability for lowering blood glucose, the effect of the treatment with the hydro-alcoholic extract of Pr on the lipid profile of normal and hyperglycemic mice was evaluated with this dose, through the determination of TC, TG, HDL-c, LDL-c, VLDL-c in serum after obtaining the blood samples by cardiac puncture, at the end of the experiment. In order to analyze the data obtained when measuring these parameters, the referenced values published (RESBCAL, 2012; Zuñiga et al., 2011) were considered and the values range are indicated in the figures.

Regarding the level of cholesterol (Table 2; Fig. 4A) although in the groups of hyperglycemic animals the cholesterol level was higher than in the normoglycemic group, this difference was not significant, the total serum cholesterol concentrations of all groups were found within the range considered normal for this species (up to $140 \mathrm{mg} / \mathrm{dl}$; Zuñiga et al., 2011). In the same way, it was found that HDL cholesterol concentrations in all the groups were kept in the normal range. The normoglycemic animals treated with $P$. ruscifolia, significantly increased $(p<0.0001)$ the TG level (NPr: $135.0 \pm 20.61 \mathrm{mg} / \mathrm{dl}$ ), compared to the control group (Nveh, $39.75 \pm 7.246 \mathrm{mg} / \mathrm{dl})$. However, the Hveh groups $(38.13 \pm 12.86$ $\mathrm{mg} / \mathrm{dl})$ and HPr $(43.88 \pm 17.21 \mathrm{mg} / \mathrm{dl})$ have TG level similar to each other and to the Nveh group ( $p>0.05$; Fig. 4B). In the same manner triglycerides increased, VLDL level was also elevated in the NPr group $(27.00 \pm 4.122 \mathrm{mg} / \mathrm{dl})$, being significantly different $(p<0.0001)$ from Nveh $(7.950 \pm 1.449 \mathrm{mg} / \mathrm{dl})$, Hveh $(5.950 \pm$ $1.140 \mathrm{mg} / \mathrm{dl})$, and HPr groups $(8.775 \pm 3.442 \mathrm{mg} / \mathrm{dl})$, which in turn showed relatively similar levels to each other $(p>0.05)$. No difference was found in LDL levels, it was observed in both groups of hyperglycemic animals, Hveh $(90.30 \pm 12.24 \mathrm{mg} / \mathrm{dl})$ and $\operatorname{HPr}(70.73 \pm 29.90 \mathrm{mg} / \mathrm{dl})$, a non-significant increase in LDL compared to control group (Nveh: $53.97 \pm 19.98 \mathrm{mg} / \mathrm{dl}$, Table 2; Fig. 5B).

Table 1. Variation of glycemia values after oral administration of hydro-ethanolic extract of Prosopis ruscifolia $(100 \mathrm{mg} / \mathrm{kg}$, p.o.) in normo- and hyperglycemic mice during 28 days.

\begin{tabular}{llccc}
\hline \multirow{2}{*}{ Group } & \multirow{2}{*}{ Treatment } & \multicolumn{2}{c}{ Mean serum glucose level (mg/dl) } & Difference \\
\cline { 3 - 5 } & & \multicolumn{1}{c}{ Initial } & Final & \% \\
\hline Nveh & Water & $139.0 \pm 12.12$ & $128.2 \pm 17.66$ & -7.77 \\
NPr & Pr & $95.88 \pm 19.94$ & $102.4 \pm 15.11$ & 6.80 \\
Hveh & Water & $418.0 \pm 61.48$ & $331.9 \pm 103.2$ & -20.60 \\
HPr & Pr & $323.3 \pm 91.73$ & $131.6 \pm 27.36$ & -59.29 \\
\hline
\end{tabular}

Data are given as mean \pm standard deviation, $n=8$.

Table 2. Lipid profile after 28 days treatment of normo and hyperglycemic mice with hydro-ethanolic extract of Prosopis ruscifolia $(100 \mathrm{mg} / \mathrm{kg}$, p.o.).

\begin{tabular}{lccccc}
\hline \multirow{2}{*}{ Group } & \multicolumn{5}{c}{ Mean serum lipid level (mg/dl) } \\
\cline { 2 - 6 } & TC & HDL & TG & VLDL & LDL \\
\hline Nveh & $95.13 \pm 28.81$ & $46.00 \pm 32.78$ & $39.75 \pm 7.246$ & $7.950 \pm 1.449$ & $53.97 \pm 19.98$ \\
NPr & $115.0 \pm 43.38$ & $34.50 \pm 12.17$ & $135.0 \pm 20.61$ & $27.00 \pm 4.122$ & $46.57 \pm 31.53$ \\
Hveh & $132.4 \pm 15.93$ & $32.25 \pm 7.649$ & $38.13 \pm 12.86$ & $5.950 \pm 1.140$ & $90.30 \pm 12.24$ \\
HPr & $139.0 \pm 12.12$ & $41.50 \pm 16.48$ & $43.88 \pm 17.21$ & $8.775 \pm 3.442$ & $70.73 \pm 29.90$ \\
\hline
\end{tabular}

Data are given as mean \pm standard deviation, $n=8$. 

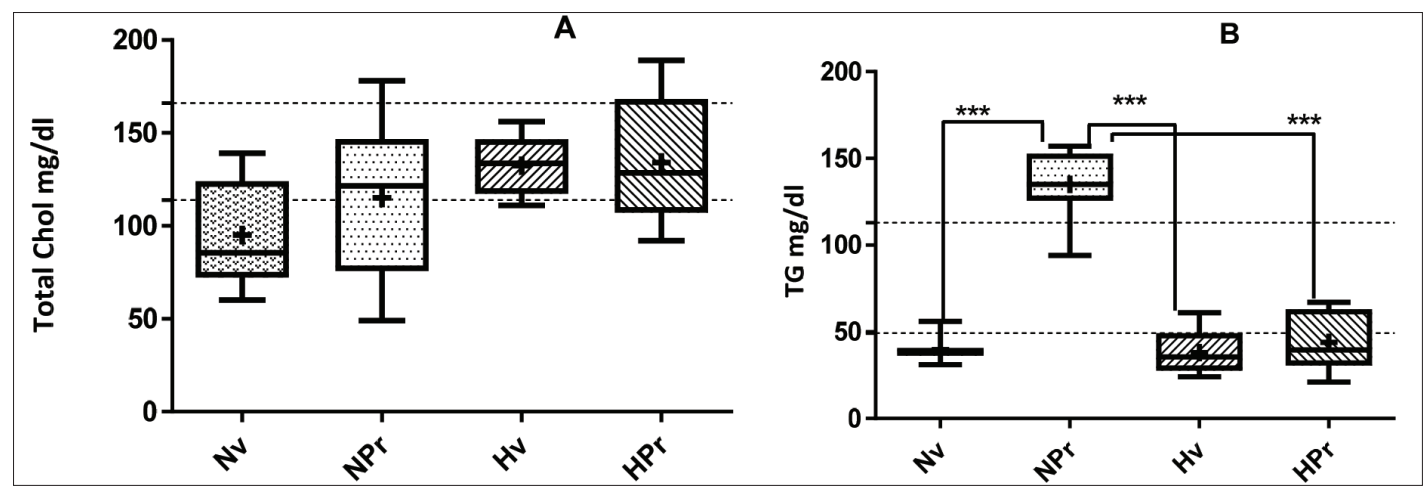

Figure 4. Cholesterol (A) and triglycerides (B) levels in hyperglycemic mice serum after 28 days treatment with $100 \mathrm{mg} / \mathrm{kg}$, p.o., Prosopis ruscifolia. Each bar represents the mean \pm SD of eight animals. ${ }^{* *} p<0.001$, significantly different from Nv, Tukey's Multiple Comparison test after one way ANOVA.

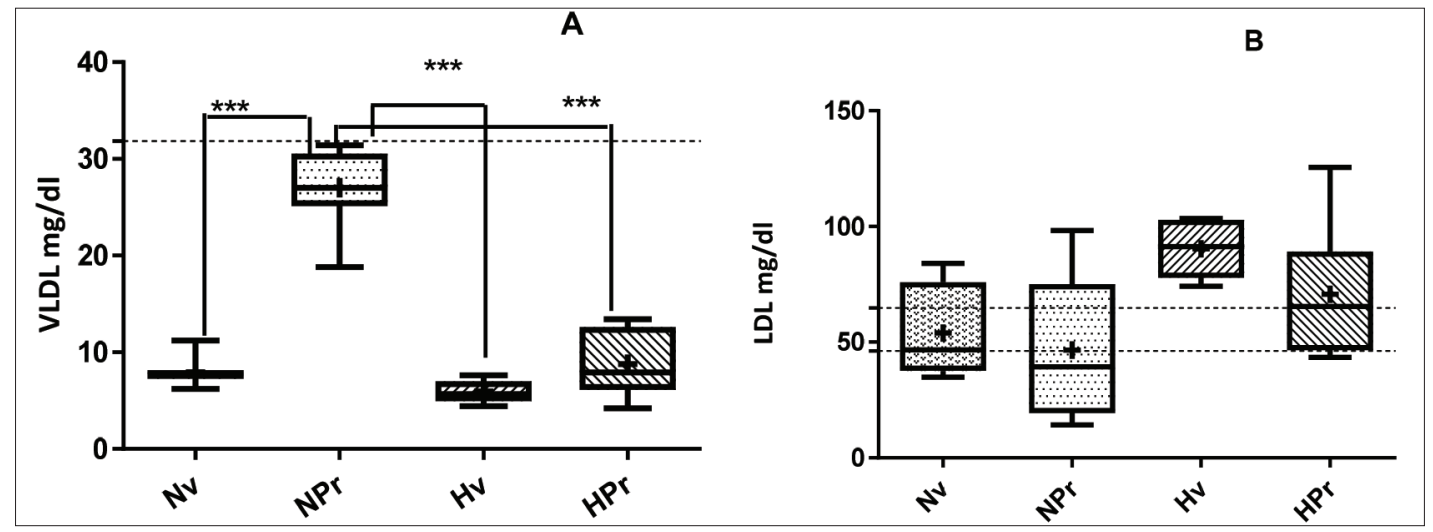

Figure 5. VLDL (A) and LDL (B) levels in hyperglycemic mice serum after 28 days treatment with $100 \mathrm{mg} / \mathrm{kg}$, p.o., Prosopis ruscifolia. Each bar represents the mean \pm SD of eight animals. ${ }^{* *} p<0.001$, significantly different from Nv, Tukey's Multiple Comparison test after one way ANOVA.

Additionally, the CRI was calculated, the results showed a significant difference between the group of hyperglycemic animals treated with vehicle (Hveh) and the control group (Nveh), on day 28 ( $p<0.05$; CRI: $4.118 \pm 1.155$ and $2.636 \pm$ 0.9597 , respectively; Fig. 6A). Regarding the AI, a significant difference $(p<0.05)$ between the group of normoglycemic and hyperglycemic animals treated with water (Nveh: $1.686 \pm$ 0.4080; Hveh: $2.889 \pm 0.8197)$ was evidenced. Moreover, the atherogenic index calculated for $\mathrm{NPr}(1.393 \pm 0.4215)$ and $\mathrm{HPr}$ $(2.009 \pm 0.6896)$ did not differ from the control group $(p<0.05$; Fig. 6B).

High TG concentration, reduced HDL-c, and increased concentration of LDL particles are characteristic features of diabetic dyslipidemia (Chehade et al., 2013), and represents a risk factor for cardiovascular disease (Mooradian, 2009). The data obtained in this study indicated a non-significant increase in total cholesterol and LDL in hyperglycemic animals treated with the vehicle during 28 days. These data are different from that reported for $P$. cineraria, after 45 days observation, where diabetic mice showed an increased level of TC, TG, LDL, and VLDL and reduced level of HDL (Sharma et al., 2010). It is likely that the longer duration of the experience helped to establish the classic triad observed in diabetic dyslipidemia. Interestingly, normoglycemic mice treated with $P$. ruscifolia showed increased levels of triglyceride and VLDL in serum. This could indicate that this plant has a stimulating action on insulin secretion, since hyperinsulinemia is also associated with an increase in the quantity of atherogenic particles of VLDL cholesterol, and triglycerides (Mooradian et al., 2007; 2008).

The LDL/HDL is a predictive value of the risk of cardiovascular disease, as well as the ratio TC/HDL, the incidence of cardiovascular disease is higher with elevated levels of LDL and low levels of HDL; therefore, the LDL/HDL ratio is often calculated to estimate cardiovascular risk (Mudhaffar, 2013). A greater ratio of $\mathrm{TC} / \mathrm{HDL}$ and $\mathrm{LDL} / \mathrm{HDL}$ represents a greater risk due to the imbalance between cholesterol molecules transported by atherogenic lipoproteins and those transported by antiatherogenic lipoproteins. The TC/HDL ratio, but not high levels of cholesterol or low levels of high-density lipoprotein, was associated with coronary hearth diseases. The LDL/HDL ratio appears to be slightly higher predictive power compared with the TC/HDL-C ratio (Zhu et al., 2015). According to the data obtained, the treatment with $P$. ruscifolia reduced the AI and CRI compared to hyperglycemic and untreated animals. It is expected that the extract will reduce the progression of atherosclerosis in mice and can be useful to prevent or reduce cardiac complication of diabetes 


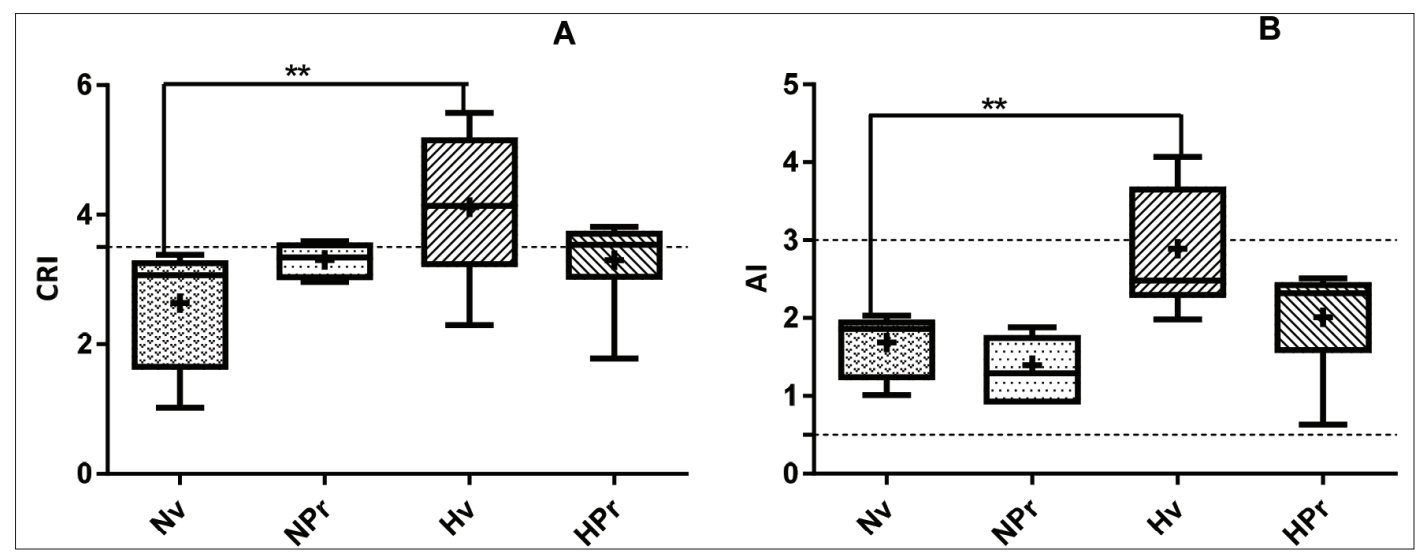

Figure 6. CRI and AI in normo- and hyperglycemic mice serum after 28 days treatment with $100 \mathrm{mg} / \mathrm{kg}$, p.o., Prosopis ruscifolia. Each bar represents the mean $\pm \mathrm{SD}$ of eight animals. ${ }^{*} p<0.01$, significantly different from Nv, Tukey's Multiple Comparison test after one way ANOVA.

hyperlipidemia. Additionally, when the atherogenic index was calculated, it was observed that normal and hyperglycemic mice treated with the extract showed a diminished value; therefore, it could be presumed that $P$. ruscifolia exerts a beneficial effect as a protector against cardiovascular diseases (Baldissera et al., 2017; Barter et al., 2007; Kang et al., 2012). Finally, controlled glucose levels in diabetes lead to reduced TC and TG levels due to decreased circulating VLDL and increased catabolism of LDL (Schofield et al., 2016).

\section{CONCLUSION}

Chronic oral administration of $P$. ruscifolia leaves extract reduced hyperglycemia and had a favorable effect in diabetic hyperlipidemia. However, further studies are necessary to confirm, extend, and clarify the underlying mechanism of observed effect. These findings are relevant because they validate the folk uses of this plant.

\section{ACKNOWLEDGMENTS}

The authors would like to thank Dr Fátima Mereles, who collected and identified the plant material.

\section{FINANCIAL SUPPORT}

None.

\section{CONFLICT OF INTEREST}

All authors have none to declare.

\section{AUTHORS' CONTRIBUTIONS}

Miguel A. Campuzano-Bublitz, María L. Kennedy, and Elena M. G. Diarte carried-out the laboratory work and the data analysis. María C. Hellión-Ibarrola and Derlis A. Ibarrola contributed to the design of the experiment and critical reading of the manuscript. Miguel A. Campuzano-Bublitz and María L. Kennedy designed the experiments and drafted the manuscript. Nelson L. Alvarenga performed the phytochemical analysis and contributed to the redaction. All the authors have read the final manuscript and approved the submission.

\section{REFERENCES}

American Diabetes Association. Classification and diagnosis of diabetes. Sec. 2. In Standards of Medical Care in Diabetes-2017. Diabetes Care, 2017; 40(Suppl. 1):S11-24.

Baigent C, Keech A, Kearney PM, Blackwell L, Buck G, Pollicino C, Kirby A, Sourjina T, Peto R, Collins R, Simes R. Efficacy and safety of cholesterol-lowering treatment: prospective meta-analysis of data from 90,056 participants in 14 randomised trials of statins. Lancet, 2005; 366:1267-78.

Baldissera MD, Souza CF, Grando TH, Stefani LM, Monteiro SG. $\beta$-caryophyllene reduces atherogenic index and coronary risk index in hypercholesterolemic rats: the involvement of cardiac oxidative damage. Chem Biol Interact, 2017; 270:9-14.

Barter P, Gotto AM, LaRosa JC, Maroni J, Szarek M, Grundy SM, Kastelein JJ, Bittner V, Fruchart JC. HDL cholesterol, very low levels of LDL cholesterol, and cardiovascular events. N Engl J Med, 2007; 357(13):1301-10.

Campuzano-Bublitz MA, Ibarrola DA, Hellion-Ibarrola MC, Dölz JH, Kennedy ML. Acute and chronic anti-hyperglycemic effect of Prosopis ruscifolia extract in normoglycemic and alloxan-induced hyperglycemic rats. J Appl Pharm Sci, 2016; 6(05):178-84.

Ceriello A. New insights on oxidative stress and diabetic complications may lead to a "causal" antioxidant therapy. Diabetes Care, 2003; 26:1589-96.

Chahil TJ, Ginsberg HN. Diabetic dyslipidemia. Endocrinol Metab Clin North Am, 2006; 35:491-510.

Chehade JM, Gladysz M, Mooradian AD. Dyslipidemia in type 2 diabetes: prevalence, pathophysiology, and management. Drugs, 2013 73:327-39.

Chillarón JJ, Sales MP, Flores Le-Roux JA, Castells I, Benaiges D, Sagarra E, Botet JP. Dislipidemia aterogénica en pacientes con diabetes mellitus tipo 1. Med Clin, 2013; 141(11):465-70.

Chillarón JJ, Flores Le-Roux JA, Goday A, Benaiges D, Carrera MJ, Puig J, Cano-Pérez JF, Botet JP. Metabolic syndrome and type 1 diabetes mellitus: prevalence and associated factors. Rev Esp Cardiol, 2010; 63(4):423-9.

Chillarón JJ, Goday A, Flores Le-Roux JA, Benaiges D, Carrera MJ, Puig J, Cano-Pérez JF, Botet JP. Estimated glucose disposal rate in assessment of the metabolic syndrome and microvascular complications in patients with type 1 diabetes. J Clin Endocrinol Metab, 2009; 94:3530-4.

Dashtban M, Sarir H, Omidi A. The effect of Prosopis farcta beans extract on blood biochemical parameters in streptozotocin induced diabetic male rats. Adv Biomed Res, 2016; 5:116, 1-4. 
Dos Santos ET, Pereira MLA, da Silva CFPG, Souza-Neta LC, Geris R, Martins D, Batista R. Antibacterial activity of the alkaloidenriched extract from Prosopis juliflora pods and its influence on in Vitro ruminal digestion. Int J Mol Sci, 2013; 14:8496-516.

Dunn JS, McLetchie NGB. Experimental alloxan diabetes in the rat. Lancet, 1943; 245:484-7.

García M, Morán A, Martín ML, Barthelmebs M, San Román L. The nitric oxide synthesis/pathway mediates the inhibitory serotoninergic responses of the pressor effect elicited by sympathetic stimulation in diabetic pithed rats. Eur J Pharmacol, 2006; 537:126-34.

George C, Lochner A, Huisamen B. The efficacy of Prosopis glandulosa as antidiabetic treatment in rat models of diabetes and insulin resistance. J Ethnopharmacol, 2011; 137:298-304.

Gerich JE. Oral hypoglycemic agents. N Engl J Med, 1989; 321:1231-45.

González Torres DM. Catálogo de Plantas Medicinales (y Alimenticias y Útiles) usadas en Paraguay. Asunción, El País, p. 403, 1996.

Hachem SB, Mooradian AD. Familial dyslipidaemias: an overview of genetics, pathophysiology and management. Drugs, 2006; 66(15):1949-69.

Kang HT, Kim JK, Kim JY, Linton JA, Yoon JH, Koh SB. Independent association of TG/HDL-c with urinary albumin excretion in normotensive subjects in a rural Korean population. Clin Chimica Acta, 2012; 413:319-24.

Lenzen S. The mechanisms of alloxan- and streptozotocininduced Diabetes. Diabetologia, 2008; 51:216-26.

Meloni DA, Gulotta MR, Martínez CA. Prosopis ruscifolia Griseb. (viñal) tolera concentraciones salinas equivalentes al agua de mar y excluye iones tóxicos de la parte aérea. Quebracho, 2008; 16:32-40.

Mooradian AD, Haas MJ, Wehmeier KR, Wong NC. Obesityrelated changes in high density lipoprotein metabolism. Obesity, 2008; 16(6):1152-60.

Mooradian AD. Dyslipidemia in type 2 diabetes mellitus. Endocrinol Metabol, 2009; 5(3):150-9.

Mooradian MD, Albert SG, Haas MJ. Low serum high-density lipoprotein cholesterol in obese subjects with normal serum triglycerides: the role of insulin resistance and inflammatory cytokines. Diabetes Obes Metab, 2007; 9:441-3.

Mudhaffar SK. Atherogenic index of plasma (AIP) as a parameter in predicting cardiovascular risk in males compared to the conventional dyslipidemic indices (cholesterol ratios). Karbala J Med, 2013; 6(1):150613

Nakano H, Nakajima E, Hiradate S, Fujii Y, Yamada K, Shigemori H, Hasegawa K. Growth inhibitory alkaloids from mesquite (Prosopis juliflora (Sw.) DC.) leaves. Phytochemistry, 2004; 65:587-91.
RESBCAL. Perfil bioquímico dos animais de Laboratório do biotério da Faculdade de Medicina de USP. RESBCAL, Sao Paulo, 2012.

Polini G, Romero R. Comer del monte. Plantas medicinales del Chaco Central. Cooperazione Internazionale Asunción, Paraguay, 2013.

Real Decreto 17344,1201/2005. Sobre protección de los animales utilizados para experimentación y otros fines científicos. Ministerio de la Presidencia- España, BOE 252, 34367-34391, 2005.

Schofield JD, Liu Y, Rao-Balakrishna P, Malik RA, Soran H. Diabetes dyslipidemia. Diabetes Ther, 2016; 7:203-19.

Sharma D, Singla YP. Evaluation of antihyperglycemic and antihyperlipidemic activity of Prosopis cineraria (Linn.) in wistar rats. J Sci Innovat Res, 2013; 2(4):751-8.

Sharma N, Garg V, Paul A. Antihyperglycemic, antihyperlipidemic and antioxidative potential of Prosopis cineraria bark. Indian J Clin Biochem, 2010; 25(2):193-200.

Singh S, Verma SK. Study of the distribution profile of piperidine alkaloids in various parts of Prosopis juliflora by the application of Direct Analysis in Real Time Mass Spectrometry (DART-MS). Nat Prod Bioprospect, 2012; 2:206-9.

Vessal M, Hemmati M, Vasei M. Antidiabetic effects of quercetin in streptozotocin-induced diabetic rats. Comp Biochem Physiol C Toxicol Pharmacol, 2003; 135C: 357-64.

Zhu L, Lu Z, Zhu L, Ouyang X, Yang Y, He W, Feng Y, Yi F, Song Y. Lipoprotein ratios are better than conventional lipid parameters in predicting coronary heart disease in Chinese Han people. Kardiologia Polska, 2015; 73:931-8.

Zúñiga J, Orellana J, Tur J. Ciencia y tecnología del animal de laboratorio. 2nd edition, Univ. Alcalá and SECAL, Madrid, 2011.

How to cite this article:

Campuzano-Bublitz MA, Diarte EMG, Hellión-Ibarrola MC, Ibarrola DA, Alvarenga NL, Kennedy ML. Effect of Prosopis ruscifolia on lipid profile in alloxan-induced hyperglycemic mice and chemical characterization of alkaloid and flavonoid fractions. J Appl Pharm Sci, 2019; 9(06):086-093. 